\title{
Iodine content development in raw cow's milk in three regions of the Czech Republic between the years 2008 and 2018
}

\author{
Roman Konečný, Zuzana Kř́žžová, Jan Hladký, Jitka Kautská, Lucie Hasoňová, \\ Eva Samková, Kristýna Šimák Líbalová, Jan Trávníček
}

University of South Bohemia in České Budějovice, Faculty of Agriculture, České Budějovice, Czech Republic

Received August 8, 2018

Accepted June 13, 2019

\begin{abstract}
The study examines an analysis and evaluation of iodine content in raw cow's milk in three regions of the Czech Republic between the years 2008 and 2018. Bulk milk samples were collected at dairy farms situated in South Bohemia, Central Bohemia, and the Vysočina Region. Iodine in milk was determined on the basis of alkaline ashing, using the spectrophotometric method according to Sandell-Kolthoff. The highest mean iodine content was measured in $2009(485.5 \pm 408.2 \mu \mathrm{g} / \mathrm{l})$ and the lowest in $2016(169.2 \pm 71.7 \mu \mathrm{g} / \mathrm{l})$. Since 2010 there has been a gradual decline of iodine concentration, from $479.5 \pm 304.9 \mu \mathrm{g} / 1$ in 2010 to $231.2 \pm 63.5 \mu \mathrm{g} / \mathrm{l}$ in 2018. A similar decreasing tendency was recorded in all the monitored regions. The percentage of samples containing iodine above $500 \mu \mathrm{g} / \mathrm{l}$ was on the decrease $(37 \%$ in $2009 ; 0 \%$ in 2016-2018) and less than $80 \mu \mathrm{g} / 1$ (8\% in 2009; $0 \%$ in 2017-2018). The current state corresponds to the requirements for iodine content in milk for human consumption. The study emphasizes the importance of continuous iodine content checks in milk and the related adjustments of iodine supplementation to the feeding rations of dairy cows.
\end{abstract}

Iodine concentration, nutrition, dairy farms, bulk samples

Iodine is an essential trace element for humans due to its incorporation in thyroid hormones which affect many biological processes in the human body (Zimmermann 2011; Flachowsky et al. 2014; Nerhus et al. 2018). As a result of this, iodine deficiency or excess may have a negative effect on human health. Many studies reveal that the population exposed to the highest risks of iodine deficiency are pregnant and breastfeeding women, children and also the elderly (Ǩehůřková et al. 2010; Zamrazil et al. 2010; Bílek et al. 2016; Ryšavá et al. 2016). The risks of excessive intake were recorded in children of up to 10 years of age (Řehůřková et al. 2010).

The iodine sources in human nutrition are represented by foods with a natural iodine content (milk, eggs, fish, and chicken meat), food fortified with iodine (salt, bread and bakery products, dairy products, meat products) or nutritional supplements (Leung and Braverman 2014; Steinhauserová et al. 2014). In the Czech Republic as well as in other countries, milk and dairy products represent the most important iodine sources due to their relatively high consumption (Dahl et al. 2003; Řehůřková and Ruprich 2013; Kř́ižová et al. 2014; Ryšavá et al. 2016; Van der Reijden et al. 2017; Dahl et al. 2018). For example, in 2017 the average annual milk and dairy product consumption was 240 litres per capita (CZSO 2017).

The iodine content in cow's milk mainly depends on its intake in the feeding ration (Troan et al. 2015). Low iodine level in the fodder, and consequently, in milk, is mainly affected by its supplementation in feeding rations (Trávníček et al. 2004). Kursa et al. (1998) reported that the iodine content in milk from cows without iodine supplements did not 
exceed $50 \mu \mathrm{g} / 1$ and often dropped below $20 \mu \mathrm{g} / \mathrm{l}$ (with clinical signs of iodine deficiency). The optimal iodine content in milk for the necessary iodine supply to dairy cows and also with respect to milk consumers ranges between 100 and $200 \mu \mathrm{g} / \mathrm{l}$ (Trávníćek et al. 2011).

Values of less than $80 \mu \mathrm{g} / \mathrm{l}$ reflect a low iodine intake due to thyroid gland activity in high-yielding dairy cows. Values higher than $250 \mu \mathrm{g} / \mathrm{l}$ are related to its excessive intake (Trávníček et al. 2011). The determination of proportional iodine intake by cows is connected with the presence of goitrogenic substances in the feeding ration (glucosinolates, isoflavones, perchlorates, bromides, nitrates and others) reducing the use of iodine for the synthesis of thyroid hormones (Pailan and Singhal 2007; Leung et al. 2012; Flachowsky et al. 2014). Prevention of iodine deficiency, which is manifested by low iodine concentration in milk, reduced milk production and thyropathies in calves during the intrauterine development, consists of sufficient iodine supplementation during gestation and lactation. The iodine content in cow's milk has been systematically monitored in the Czech Republic since the 1990s. Between 1988 and 1996, the mean iodine concentration decreased to $31 \mu \mathrm{g} / \mathrm{l}$ as a result of insufficient supplementation (Kursa et al. 1998). Between 1997 and 1999, the mean iodine content in milk increased to $128 \mu \mathrm{g} / \mathrm{l}$, as a result of enhanced care for mineral nutrition of high-yielding dairy cows. After 2000, there was a steep rise in iodine concentration in milk which reached a mean concentration of $310 \mu \mathrm{g} / \mathrm{l}$ of milk in 2003 (Kursa et al. 2005).

The aim of this work was to evaluate the development of iodine content in cow's milk at dairy farms situated in three regions of the Czech Republic between 2008 and 2018.

\section{Materials and Methods}

Iodine content was monitored in bulk milk samples of raw milk collected between 2008 and 2018 at dairy farms in South Bohemia, Central Bohemia, and the Vysočina Region (Table 1). The milk samples were taken from milk tanks at the given breeding farms. The samples were taken using the same method as for the determination of quality performed by qualified employees of the dairy farm. The samples were frozen in standard sampling bottles on the day of sampling and kept at $-15^{\circ} \mathrm{C}$ for 4 to 6 weeks before analysis. Iodine in milk was determined on the basis of alkaline ashing using the spectrometric method of Sandell-Kolthoff (Kursa et al. 2005). The principle behind determination is the reduction of $\mathrm{Ce}^{4+}$ to $\mathrm{Ce}^{3+}$, in the presence of $\mathrm{As}^{3+}$ due to the catalytic effect of iodine. Dry mineralisation takes place in the alkaline environment at $600{ }^{\circ} \mathrm{C}$. The above described method was used to determine total iodine (inorganically and organically bound iodine to proteins). Statistical processing of data included the average values (means), standard deviations (SD), minimum and maximum values, median; significance was determined by the ANOVA - Tukey's test. Data were evaluated by STATISTICA 9.0. (StatSoft, Inc.).

Table 1. Iodine content in bulk samples of cow's milk $(\mu \mathrm{g} / \mathrm{l})$ in 2008-2018.

\begin{tabular}{|c|c|c|c|c|c|c|c|c|}
\hline \multirow{2}{*}{ Year } & \multicolumn{2}{|c|}{ Number } & \multirow[t]{2}{*}{ Mean \pm SD } & \multirow[t]{2}{*}{ Min } & \multirow[t]{2}{*}{ Max } & \multirow[t]{2}{*}{ Median } & \multicolumn{2}{|c|}{ PCTL } \\
\hline & Samples & $\overline{\text { Herds }}$ & & & & & 0.25 & 0.75 \\
\hline 2008 & 78 & 78 & $390.1 \pm 250.0$ & 28.2 & 1258.0 & 310.8 & 207.6 & 555.7 \\
\hline 2009 & 140 & 70 & $485.5 \pm 408.2^{\mathrm{a}}$ & 13.4 & 2840.0 & 292.2 & 189.6 & 800.8 \\
\hline 2010 & 70 & 70 & $479.5 \pm 304.9^{b}$ & 70.4 & 1332.0 & 435.0 & 223.8 & 612.8 \\
\hline 2011 & 84 & 42 & $402.2 \pm 380.8^{c}$ & 21.0 & 1502.0 & 267.5 & 164.0 & 596.0 \\
\hline 2012 & 80 & 40 & $344.1 \pm 354.0^{1}$ & 22.0 & 2080.0 & 232.5 & 127.7 & 440.0 \\
\hline 2013 & 90 & 45 & $292.2 \pm 264.1^{2}$ & 24.0 & 1200.0 & 224.0 & 145.7 & 296.2 \\
\hline 2014 & 108 & 54 & $219.3 \pm 87.4^{3}$ & 50.0 & 456.0 & 229.0 & 140.0 & 292.5 \\
\hline 2015 & 150 & 75 & $243.7 \pm 129.9^{4}$ & 35.0 & 688.0 & 240.0 & 152.8 & 306.0 \\
\hline 2016 & 70 & 70 & $169.2 \pm 71.7^{5}$ & 40.0 & 316.0 & 158.0 & 112.7 & 227.5 \\
\hline 2017 & 70 & 70 & $209.7 \pm 53.6^{6}$ & 90.0 & 308.0 & 209.0 & 174.0 & 260.0 \\
\hline 2018 & 70 & 70 & $231.2 \pm 63.5^{7}$ & 110.0 & 460.0 & 228.0 & 210.0 & 265.0 \\
\hline
\end{tabular}

a:2,3,4,5,6,7$P<0.01 ;{ }^{\text {b: } 1} P<0.05 ;{ }^{\text {b:2,3,4,5,6,7 }} P<0.01 ;{ }^{\mathrm{c}: 3,4,5,6,7} P<0.01 ; \mathrm{SD}-$ standard deviation, PCTL - percentile 


\section{Results}

Iodine content development in dairy cow's milk is shown in Table 1. The highest mean iodine content $(485.5 \pm 408.2 \mu \mathrm{g} / \mathrm{l})$ was found in the samples taken in 2009. Since 2010, the mean values were significantly $(P<0.01)$ decreasing, even more markedly since 2014 . Table 1 also clearly shows a decrease in both the mean iodine content and the maximum values of iodine. In 2012 the maximum iodine values reached $2080.0 \mu \mathrm{g} / \mathrm{l}$, followed by a sharp drop in 2014 with only $456.0 \mu \mathrm{g} / \mathrm{l}$ and $460.0 \mu \mathrm{g} / \mathrm{l}$ in 2018 .

The recorded minimum iodine value ranging from 13.4 to $70.4 \mu \mathrm{g} / \mathrm{l}$ indicates the existence of dairy farms with a significant iodine deficiency in the feed rations (Table 1).

An overview of the relative representation (\%) of the samples by iodine content is shown in Table 2. Samples with a low iodine content (less than $80 \mu \mathrm{g} / \mathrm{l}$ ) did not occur in 2017 and 2018. During the reporting period their occurrence culminated between 2011 and 2013 (from $12 \%$ to $19 \%$ ). Proportion of the samples with a standard iodine content $(80-250 \mu \mathrm{g} / \mathrm{l}$ ) did not exceed 46\% between 2008 and 2015. Between 2016 and 2018 their representation increased up to $74-73 \%$. However, the samples proportion reflecting excessive iodine intake decreased between 2016 and 2018. Samples with an iodine content of 250-500 $\mu \mathrm{g} / \mathrm{l}$ were represented by $13-27 \%$, and samples containing more than $500 \mu \mathrm{g} / \mathrm{l}$ were no longer present between 2016 and 2018 .

Table 2. Relative proportion (\%) of samples by iodine content in cow's milk in 2008-2018.

\begin{tabular}{|c|c|c|c|c|c|c|c|c|c|c|c|}
\hline \multirow{2}{*}{$\begin{array}{l}\text { Iodine content } \\
\text { in samples }(\mu \mathrm{g} / \mathrm{l})\end{array}$} & \multicolumn{11}{|c|}{$\%$ samples } \\
\hline & 2008 & 2009 & 2010 & 2011 & 2012 & 2013 & 2014 & 2015 & 2016 & 2017 & 2018 \\
\hline$<80$ & 5 & 7 & 1 & 12 & 12 & 19 & 6 & 8 & 13 & 0 & 0 \\
\hline $80-250$ & 31 & 32 & 21 & 29 & 43 & 38 & 33 & 46 & 74 & 73 & 73 \\
\hline $250-500$ & 32 & 24 & 31 & 33 & 26 & 27 & 45 & 39 & 13 & 27 & 27 \\
\hline$>500$ & 32 & 37 & 47 & 26 & 19 & 16 & 16 & 7 & 0 & 0 & 0 \\
\hline
\end{tabular}

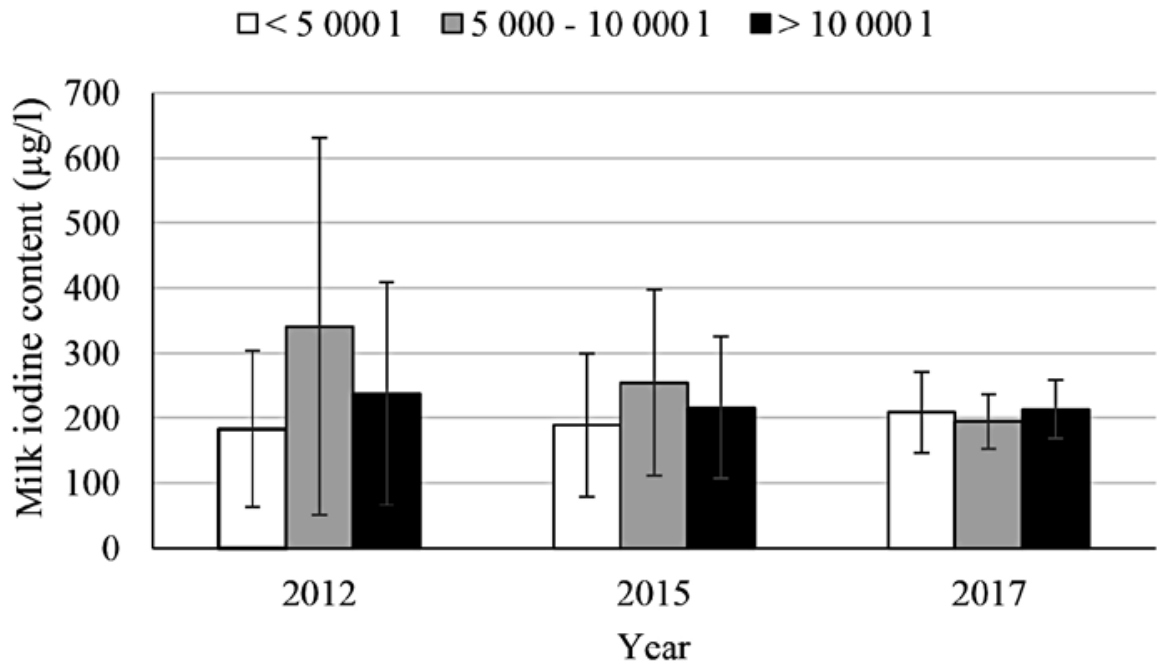

Fig. 1. Development of iodine content in milk $(\mu \mathrm{g} / \mathrm{l})$ depending on the daily milk production on the farm 
The relationship between the amount of milk delivered daily for dairy processing and iodine content in a bulk sample is shown in Fig. 1. A lower iodine content was found at the dairy farms producing up to 5000 litres of milk per day and the highest at the dairy farms producing 5000 to 10000 litres of milk per day. The highest difference was discovered in 2012, the lowest in 2017. The most balanced iodine content was found at the dairy farms with the highest daily milk production (over 10000 litres).

This study also focused on regional differences in the iodine content (Fig. 2). However, during the reporting period, significant differences were recorded only in 2017 . Figure 2 shows that since 2014 the dispersion of values was decreasing in percentile 0.75 along with the decreasing iodine content in milk (Table 1).

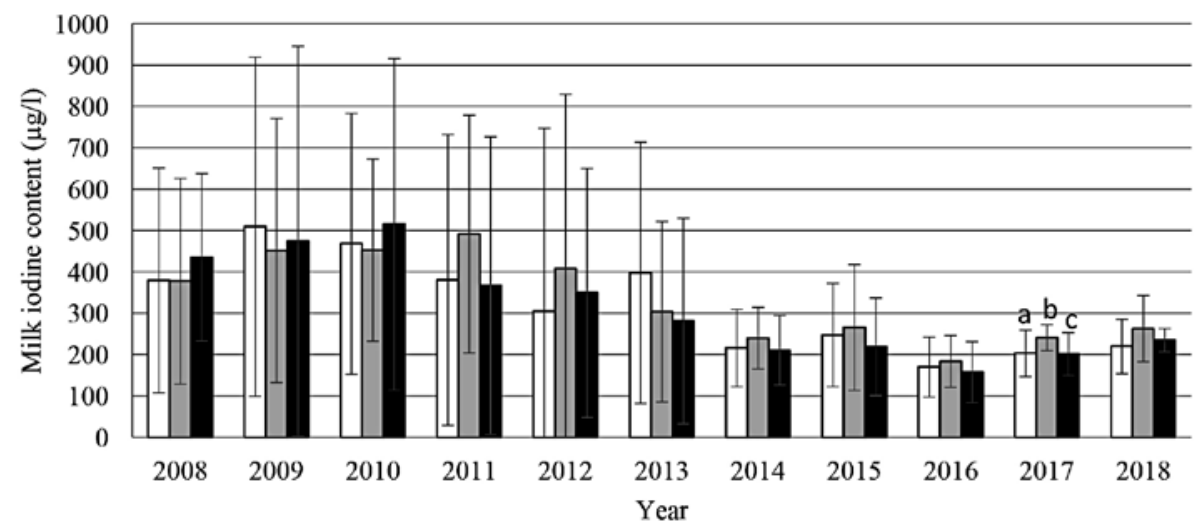

Fig. 2. Development of iodine content in milk $(\mu \mathrm{g} / 1)$ in three regions of the Czech Republic a:b $P<0.01$, b:c $P<0.05$

\section{Discussion}

This study deals with the iodine content development in cow's milk in three regions of the Czech Republic in the last eleven years (2008-2018). Bulk milk samples were collected at dairy farms situated in South Bohemia, Central Bohemia, and the Vysočina Region. The work follows from the extensive study of Kursa et al. (2005) and the study of Trávníček et al. (2006) who monitored the iodine content in milk between 2003 and 2005. Both authors recorded a marked increase in the iodine content in milk compared to the previous 10 years. Based on an analysis of 226 bulk samples, Kursa et al. (2005) noted a mean iodine content of $310.4 \mu \mathrm{g} / \mathrm{l}$ milk. In 2005, Trávníček et al. (2006) analysed milk samples from 169 bulk transportation tanks with an iodine value of $442.5 \mu \mathrm{g} / \mathrm{l}$. The increase in iodine content in milk was the result of targeted iodine supplementation in feeding rations of dairy cows initiated between 1997 and 1999. The increased supplementation responded to the insufficient subsidy of feed rations and an increased intake of goitrogens contained in the feed of plant origin (Trávníček et al. 2011).

The recorded high iodine content in raw cow's milk and milk used for commercial purposes indicated the potential risk of excess iodine in the selected population group (Trávníček et al. 2011; Kavřík et al. 2018; Nejedlá 2018). As a result of these findings, the Intersectoral Committee on Iodine Deficiency Solution responded by recommending 
a reduction of the maximum iodine content in cow's milk mineral feed supplements (Nejedlá 2018). The iodine content in the cow's milk feed was also regulated via Commission Regulation (EC) No. 1459/2005, decreasing the maximum iodine content in dairy cows feed to $5 \mathrm{mg} / \mathrm{kg}$ of feed (Trávníček et al. 2011; Nejedlá 2018). After the implementation of this Regulation in 2006 , we recorded a mean iodine content in raw cow's milk amounting to $371.8 \pm 235.0 \mu \mathrm{g} / \mathrm{l}$ (data not shown). Table 2 clearly shows that between 2008 and 2009, the mean iodine content in milk temporarily increased again and in 2009 the highest value $(485.5 \mu \mathrm{g} / \mathrm{l})$ was recorded during the monitored period (2008-2018). This value was also the highest value in comparison to the other European countries (Germany $124.5 \pm 30.6 \mu \mathrm{g} / \mathrm{l}$, Poland $183.5 \pm 5.0 \mu \mathrm{g} / \mathrm{l}$, Ireland $449.0 \mu \mathrm{g} / \mathrm{l}$ ) (Köhler 2012; O’Brien et al. 2013; Śliwiński et al. 2015). Since 2010, a desirable gradual decrease in the mean iodine values in milk (Table 2) has been recorded. In 2017 and 2018 the mean and median values already met the requirements for the iodine content in milk as a food product (Kursa et al. 2005).

The results gathered from this study are slightly different compared to the data provided by the National Institute of Public Health in Brno (NIPH) which monitors the dietary exposure of the population of the Czech Republic to iodine and its most important dietary sources. In 2009, the NIPH also recorded increased mean iodine values in milk used for commercial purposes (whole and skimmed milk). However, the iodine values had an increasing tendency until 2011 ( ̌̌ ehůřková et al. 2010; Kavř́ík et al. 2018). Between 2012 and 2014, they recorded a relatively stable mean iodine content in market milk of around $250 \mu \mathrm{g} / \mathrm{l}$, which was followed by a temporarily increased mean iodine content of over $300 \mu \mathrm{g} / \mathrm{l}$ in 2015 (Kavř́k et al. 2018). This study also recorded this tendency, yet the values increased only by $11.13 \%$ to $243.7 \mu \mathrm{g} / \mathrm{l}$.

The recorded differences in dynamic and mean values were probably due to the different size of the monitored areas and numbers of the analysed samples. The NIPH analysed lower numbers of samples per year. Another factor might be the regional difference in the ratio of small and large dairy farms described by Vorlová et al. (2014).

Paulíková et al. (2008) and Crnkić et al. (2014) describe a significant difference in the iodine content in different regions of their countries. Results of this study also record regional differences in the iodine content, however, they showed significant differences $(P<0.01 ; P<0.05)$ only in 2017 (Fig. 2).

Changes in the relative proportions $(\%)$ of iodine content in samples (Table 2) confirm positive changes in the iodine saturation of dairy cows which are manifested both by the desirable decrease in mean values and the decrease in low and extremely high values (Table 1). Samples with a low iodine content (less than $80 \mu \mathrm{g} / \mathrm{l}$ ) were not present in 2017-2018 and samples containing more than $500 \mu \mathrm{g} / 1$ have not been part of our set since 2016. The balancing of the iodine content in milk between dairy farms with a different production and supply of milk for processing is also a very important finding (Fig. 1). The above facts are the results of the controlled optimization of iodine content in feeding rations in dairy farms with a daily milk production exceeding 5000 or rather 10000 litres, which significantly affects the amount of iodine in raw milk and consequently in drinking milk and dairy products.

Positive changes in the iodine content in cow's milk are related to the current systematic coverage of its content in bulk milk samples. The optimal content of iodine in cow's milk is an important contribution by the dairy industry to supplying the Czech population with iodine from natural sources.

\section{Acknowledgements}

This study was supported by Ministry of Agriculture of the Czech Republic - NAZV KUS QJ1510339, the Grant Agency of the University of South Bohemia (project No. 028/2019/Z). 


\section{References}

Bílek R, Kaňová N, Mindžáková V, Neumann D, Jiskra J, Ryšavá L, Zamrazil V 2016: Iodine supply of pregnant women in the Czech Republic (In Czech). Vnitř Lék 62: 10-16

Crnkić Ć, Haldimann M, Hodžić A, Tahirović H 2015: Seasonal and regional variations of the iodine content in milk from Federation of Bosnia and Herzegovina. Mljekarstvo 65: 32-38

CZSO. Food Consumption 2017 [online]. (C) Czech Statistical Office. 2017. Available at: https://www.czso.cz/csu/ czso/food-consumption-2017. Last modified August 9, 2019. Accessed March 12, 2019

Dahl L, Opsahl JA, Meltzer HM, Julshamn K 2003: Iodine concentration in Norwegian milk and dairy products. Brit J Nutr 90: 679-685

Dahl L, Wik Markhus M, Sanchez PVR, Moe V, Smith L, Meltzer HM, Kjellevold M 2018: Iodine deficiency in a study population of Norwegian pregnant women - results from the little in Norway study (LiN). Nutrients 10: 513

Flachowsky G, Franke K, Meyer U, Leiterer M, Schöne F 2014: Influencing factors on iodine content of cow milk. Eur J Nutr 53: 351-365

Kavř́k R, Nevrlá J, Řehůřková I, Ruprich J 2018: Iodine monitoring in the market milk in the Czech Republic (in Czech). Available at: http://www.szu.cz/uploads/documents/czzp/seminare/2018/Abstrakt_Jod_v_ mlece 2018 Kavrik. doc. Last modified March 21, 2018. Accessed March 12, 2019

Köhler M, Fech̄ner A, Leitener M, Spörl K, Remer T, Schäfner U, Jahreis G 2012: Iodine content in milk form German cows and human milk: new monitoring study. Trace Elem Electroly 29: 119-126

Křížová Z, Trávníček J, Hasoňová L, Vítková L, Staňková M 2014: Milk as an important source of iodine in human nutrition (In Czech). Mlékařské listy 147: 20-23

Kursa J, Rambeck WA, Kroupová V, Kratochvíl P, Trávníček J 1998: Occurrence of struma in cattle in the Czech Republic. Tierarztl Prax Ausg G Grosstiere Nutztiere 26: 326-331

Kursa J, Herzig I, Trávníček J, Kroupová V 2005: Milk as a food source of iodine for human consumption in the Czech Republic. Acta Vet Brno 74: 255-264

Leung AM, Braverman LE 2014: Consequences of excess iodine. Nat Rev Endocrinol 10:136-142

Leung AM, Braverman LE, He X, Schuller KE, Roussilhes A, Jahreis KA, Pearce EN 2012: Environmental perchlorate and thiocyanate exposures and infant serum thyroid function. Thyroid 22: 938-943

Nejedlá M 2018: Prevention of iodine deficiency in the Czech Republic (In Czech). Hygiena 63: 25-27

Nerhus I, Wik Markhus M, Nilsen MB, Øyen J, Maage A, Ødegård ER, Kolden Midtbø L, Frantzen S, Kögel T, Eide Graff I, Øyvind L, Dahl L, Kjellevold M 2018: Iodine content of six fish species, Norwegian dairy products and hen's egg. Food Nutr Res 62: 1291-1294

O’Brien B, Gleeson D, Jordan K 2013: Iodine concentration in milk. Irish J Agr Food Res 52: 209-216

Pailan GH, Singhal KK 2007: Effect of dietary glucosinolates on nutrient utilization, milk yield and blood constituents of lactating goats. Small Rumin Res 71: 31-37

Paulíková I, Seidel H, Nagy O, Kováč G 2008: Milk iodine content in Slovakia. Acta Vet Brno 77: 533-538

Ryšavá L, Kříž J, Kašparová L, Křížová T, Žoltá M, Lisníková P 2016: Iodine supply and iodinuria among the Czech population between the years 1995 and 2016 (In Czech). Vnitř Lék 62: 28-32

Řehưřková I, Ruprich J, Dofková M 2010: Iodine and its dietary exposition for the population of the Czech Republic (In Czech). In: Ryšavá L, Žoltá M (Eds): Sborník IX. Konference u př́ležitosti dne jódu „Zásobení jódem a prevence tyreopatií se zaměřením na období těhotenství a kojení“. Státní zdravotní ústav Praha, Praha, pp. 7-10

Řehůřková I, Ruprich J 2013: Dietary supply of iodine to Czech population and its most important sources (in Czech). In: Ryšavá L, Žoltá M (Eds) Sborník X. konference u přiležitosti dne jódu: „Zásobení jódem jako prevence tyreopatií a zdroje dietární expozice“. Státní zdravotní ústav Praha, Praha, pp. 13-19

Steinhauserová P, Řehůřková I, Ruprich J 2014: Determination of iodine and sodium content in fermented meat products purchased in the Czech Republic - a pilot study. Acta Vet Brno 83: 273-277

Śliwiński B, Brzóska F, Szybiński Z 2015: Iodine concentration in Polish consumer milk. Ann Anim Sci 15: 799-810

Trávníček J, Herzig I, Kursa J, Kroupová V, Navrátilová M 2006: Iodine content in raw milk. Vet Med-Czech 51: 448-453

Trávníček J, Kroupová V, Dušová H, Krhovjáková J, Konečný R 2011: Optimalization of iodine content in cow’s milk (In Czech). Jihočeská univerzita v Ceských Budějovicích, Agrovýzkum Rapotín. 56 p.

Trávníček J, Kroupová V, Šoch M 2004: Iodine content in bulk feeds in western and southern Bohemia. Czech J Anim Sci 49: 483-488

Troan G, Dahl L, Meltzer HM, Abel MH, Indahl UG, Haug A, Prestløkken E 2015: A model to secure a stable iodine concentration in milk. Food Nutr Res 59: 29829

Van der Reijden O, Zimmermann BZ, Galetti V 2017: Iodine in dairy milk: Sources, concentrations and importance to human health. Best Pract Res Clin Endocrinol Metab 31: 385-395

Vorlová L, Hodulová L, Borkovcová I, Přidalová H, Kostrhounová R, Klimešová-Vyletělová M, Šustová K 2014: Iodine content in bulk tank milk samples in relation to dairy farm size. Acta Vet. Brno, 83: 9-13

Zamrazil V, Bílek R, Čeřovská J, Dvořáková M, Němeček J 2010: Iodine deficiency in the world and in the Czech Republic - Current status and perspectives. Vnitř Lék 56: 1310-1315

Zimmermann BM 2011: The role of iodine in human growth and development. Semin Cell Dev Biol 22: $645-652$ 